\title{
Impact of Social Corporate Responsibility on Achieving Competitive Advantage: The Case of Hotels in the Aqaba Special Economic Zone (ASEZ), Jordan
}

\author{
${ }^{1}$ Mohammad Fadel Al Mahasneh, MSc, ${ }^{2}$ Azilah Kasim, PhD \\ ${ }^{1}$ Department of Archaeology and Tourism, Faculty of Social Sciences, Mu'tah University \\ Karak - Jordan \\ ${ }^{2}$ School of Tourism, Hospitality and Environmental Management, Universiti Utara Malaysia, \\ Malaysia \\ lmodmas@hotmail.com,2azilah@uum.edu.my
}

\begin{abstract}
This study explores the perceived impact of corporate social responsibility on competitive advantage of hotels in the context of Aqaba Special Economic Zone (ASEZ), Jordan. Past studies on this topic were predominantly within the context of non-service industries. Guided by relevant past literature, an instrument was developed and distributed to a sample of 555 respondents comprising of middle level hotel managers. The study found that effects of social responsibility dimensions on accomplishing competitive advantage explained 54\% of variance of the dependent variable (competitive advantage).This and other findings of the study led to the conclusion that hotels need to focus on social responsibility, provide the infrastructure required for performing socially responsible activities, and conduct more studies to understand community needs better.
\end{abstract}

Keywords: Hotel Impact, Social Responsibility, Competitive Advantage.

\section{INTRODUCTION}

Traditionally, business has been conditioned to achieve one goal - to make profit. This is termed as 'business as usual' and has been and is still being practiced by many businesses from all industries today especially within the context of developing and less developed world. However, it is also increasingly evident in the literature that businesses in those contexts are slowly changing their ways to embrace a more 'responsible' way to do business (see Kasim, 2009). More managers are including environmental and social considerations in they way they do business, including those in the hotel sector (Kasim, 2007).

However, socially responsible activities cost time and money. Therefore businesses do not engage in them for altruistic reason, but rather for strategic reasons. One business advantage of engaging in socially responsible activities is the improvement of company reputation as a result of effective performance (Carroll \& Shabana, 2010). This will lead to a company's success in offering services that customers want, in developing mutual trusts with other companies and interests groups and in ensuring transparency of company actions.

Being socially responsible entails consideration of investments in environmental and human capital (Al-Robaiei, 2010), which in turn will attract the best human resources to come to work for the company (Al-Hamori, 2010). In addition, being socially responsible will enable a company to build strong relations with governments and minimize litigation and social risks of not adhering to the minimum standard of environmental and labour laws particularly among small and medium sized companies (Shaw, 2008).

Social responsibility is a strategic launch point for the activities of many organizations in the developed societies, where company orientation towards community service has become just as important as the issue of competition, customer retention and quality (Victoria et al., 2002). Organizations are no longer viewed as a production unit that has the economic role of providing high quality product with moderate prices using promotional aids only. Rather, they have the role of helping individuals and community to live in a well-fared and healthy environment (Carrigan \& 
Attalla, 2001). This is especially so after many governments gave up a number of their service and economic roles in public welfare (Al-Ghalibi and Al-Amiri, 2008).

Although social responsibility has gained more recognition even within the Middle Eastern context, the transition of these roles to the private sector has not been effective in fully reducing the government's responsibility (Sweidan and Hadad, 2006). The reasons include the fact that the private sector cannot embrace social responsibility solely for altruistic reason. Rather, it needs to prioritize productivity, profit, improve labour-management relations and other traditional roles that it plays (Anselmsson and Johansson, 2007).

Although literature review reveals that there is alignment between competitive actions and socially responsible actions, this conclusion still applies only within the contexts of traditional industries. Little is known about the application of this issue on the service sector. In addition, literature review shows that most research was in the context of the developed world. Therefore we are still in the dark as to how significant is the relation between socially responsible actions and competitive advantage in a developing or a less developed country.

This study seeks to close some of the above knowledge gap by focusing on the perception of hotel middle managers in Aqaba Special Economic Zone (ASEZ) because informal conversations prior to the study commencement indicated that hotel management in this region was yet to grasp the importance of employing social responsibility in their tasks and operations. These hotels have been tied to traditional views of doing business, which limited them to a narrow strategy of progress and growth. Despite having competitive advantages in terms of product quality, they still weren't able to apply dimensions of social responsibility that are theoretically essential in creating competitive advantage. Therefore, they lack strategy on how to become more competitive in the global market.

The intense local and global competitions however, dictate that ASEZ hotels change their operational philosophy and seek new means and processes necessary to improve their offerings of products and services to meet the needs of all segments of their clients. Social responsibility is clearly an essential ingredient that could help business (including hotels) achieve competitive advantage against each other (Carroll \& Shabana, 2010). With this in mind, the objectives of this study therefore are: 1) To determine the social responsibility and its impact on hotels' competitive advantages at ASEZ; and 2) To suggest proper basis for strategies of employing the social responsibility as competitive advantage in Jordanian hotel organizations.

\section{SIGNIFICANCE OF THIS STUdY}

This study can contribute towards better understanding for planners and decision makers about the impact of social responsibility on achieving the competitive advantage of hotels at ASEZ. Since recognition of the term "social responsibility" is still at its infancy in the Arab World such as Jordan, the study findings will add specific knowledge of sustained development and new styles of management to the region. This knowledge will be helpful to an organization's survival and endurance within the global competition where modern management strategy is well adopted to help business organizations progress and overcome difficulties. This study can also serve as future reference on the topic within the context of Jordan.

\section{LITERATURE REVIEW}

\subsection{Competitive Advantage}

Jones and Hail (2001), suggest that the competitive advantage is a distinctive feature for the company against its rivals. It allows a company to strongly compete via offering of products and services with a distinctive value to its targeted customers. This is in line with Porter (1980) argument that competitive advantage is achieved when companies can deliver products and services that match the needs and values of their customers. Similarly Sharma and Kodali (2008), assert that competitive advantage is represented in the distinction of a company against its rivals in terms of innovative product, styles, or profitability.

Studies on competitive advantage in the Middle East focused on the contexts of pharmaceutical companies, banks and the manufacturing industry. Ba Rahmah (2007) for example, studied strategic option and its impact on achieving the competitive advantage within the context of the pharmaceutical companies in Yemen. The results indicate that perceptions of respondents towards strategic option 
were high but were medium towards competitive advantage, indicating an impact of strategic option on competitive advantage. Dasi (2007) studied the role of knowledge management in achieving competitive advantage for the Syrian public banks. The results showed that respondents have high perceptions towards the competitive advantage variables. The impact of knowledge management on achieving the competitive advantage was explained by $69.4 \%$ of variance in the competitive advantage variable.

Al-Talafhah (2008) studied the impact of change management on achieving competitive advantage in Jordan Telecom. The study found that change management could have an impact on the company's achievement of competitive advantage as explained by $54.4 \%$ of the variance in the competitive advantage variable.

\subsection{Dimensions of Competitive Advantage}

Eliasberg and Steinberg (1991), contend that competitive advantage can be created through reduction of costs in order to invest such cost to achieve an additional value for the cost unit. Tamimi and Khashani (2004) support this, but argue that cost reduction should be achieved through using the resources efficiently or using its know-how and expertise to fulfil its activities in a way that achieves a higher value for the customer compared to competitors.

Meanwhile, McGregor (1991) emphasizes that companies with the ability to be flexible and cooperate to overcome foreseen circumstances can also attain competitive advantage. He stresses that such companies have the leadership to balance between company performance and law obedience, achieve a democratic way of actions, enhance business flexibility in its conducts, impartial on political attitudes, and provide fair wages and remunerations, all leading to the achievement of competitive advantage. Al-Qura'an (2007) studied the impact of manufacturing flexibility on the competitive advantage of furniture companies at King Abdullah Industrial Zone at Sahab. He confirms that flexibility has a medium impact on competitive advantage.

Powel (2009) studied total quality management (TQM) as a competitive advantage for organizations. The researchers found that most organizations with distinctive TQM (i.e. focus on quality, training, improvement of processes) also have competitive advantage (in terms of open culture, employees enhancement and organizational effectiveness). Reuter et al. (2010) studied the role of vital capability in achieving the competitive advantage for the computer companies during 1984-2007 by using HAZARD model related to the strategies of transition, entry and experience for the possibilities of survival in the foreign markets. Their results showed that organizations which can aim for distinction via adoption of merger strategies and entry of foreign markets through diversification, concentration and merger achieved high rates of performance more than those organizations which invested in their own market.

The next two studies found link between innovation and competitive advantage. Ismael (2009) studied the impact of adopting information technology to achieve competitive advantage strategies in the pharmaceutical industry in Jordan. The study found that there was a statistically significant impact of using information technology on the strategies of competitive advantage. Al-Shishani (2009) studied the impact of information technology and advanced telecommunication technology on acquiring competitive advantage for Jordan Telecom. The study results showed there was an impact of both types of innovation on acquiring a competitive advantage by the company. This result explained $64.8 \%$ of the variance in the competitive advantage of Jordan Telecom.

All of the above works indicate that competitive advantage can be described as having several dimensions: low cost advantage, flexibility, delivery, distinction and innovation.

\subsection{Dimensions of Social Responsibility}

Responsible business has been an increasingly accepted way of doing business. The hotel sector is not excluded from this trend, with increasing number of hotels seen projecting themselves as environmentally and socially responsible (see Kasim, 2009). Table 1 below gives example of responsible actions hotels take in their daily operation. 
Table1. Examples of Socially Responsible Action Within the Hotel Context

\begin{tabular}{|c|c|}
\hline Social responsibility & Examples of Social Responsibility in Hotels \\
\hline - $\quad$ Economic dimension. & $\begin{array}{l}\text { - Providing local employment, generating spill over } \\
\text { businesses }\end{array}$ \\
\hline - $\quad$ Environmental dimension & $\begin{array}{l}\text { - Using energy saving lighting and/or water saving } \\
\text { devices }\end{array}$ \\
\hline - $\quad$ Human dimension. & - $\quad$ Investing in human resources \\
\hline - $\quad$ Technological dimension & $\begin{array}{ll}\text { - } & \begin{array}{l}\text { Investing in technology to improve business } \\
\text { processes }\end{array}\end{array}$ \\
\hline - $\quad$ Social dimension. & $\begin{array}{l}\text { - Reaching out to the local community through } \\
\text { charity activities }\end{array}$ \\
\hline
\end{tabular}

Eweje and Bently (2006) categorized three criteria for success in socially responsible companies: respect and responsibility towards employees and society (social dimension), protection of environment whether through distinctive and innovative product that is compatible with environment or serves the environment, and improvement of the environmental conditions and environmental problems (environmental dimension).

Smith and Grossbois (2010) studied the adoption of social responsibility by airlines companies and found significance of the environmental dimension of social responsibility. The study found that airline companies prioritize liability issues related to the environment more than the economic and social aspects. The study also found that there were initiatives of airlines companies to reduce the environmental impacts of this industry in terms of radiations, wastes, energy, water, biodiversity and noise.

Annadi (2008) studied social responsibility in Egypt and its role in developing the creative capabilities of employees. The study found links between social responsibility with attributes such as market development, competitiveness, skilfulness of production teams, service and marketing (economic dimension). Al-Hamdi and Ja'abal (2008) who studied the perception of managers on the social responsibility concept at a manufacturing organization in Yemen found that social responsibility is equated with positive feeling of social responsible activities (social dimension). Those feel good activities include offering of healthy and safe products to customers, offering of good quality products, conducting ethical marketing and participating in local events.

Al-Turkustani (2009) study on Saudi companies found two dimensions social responsibility practiced by those companies: the environmental dimension (including contribution to protection of environment) and the human dimension (including community awareness, expanding education, commercial fraud against society protection, charity, socio-cultural projects, reducing unemployment and training).

Victoria, Jjohnson \& Brennan (2002) suggest that technology also applies in the abstraction and realization of social responsibility. They point to the growth Socially Responsible Investment Organizations (SRIOs) that use technology to identify and research companies and communicate investors' demands and concerns to corporate management. Corporate managers also use technology to develop mechanisms for managing vital information to various stakeholders. This means that there is a technological dimension to social responsibility.

\subsection{Social Responsibility and Competitive Advantage}

Social responsibility gives companies a good image and protects them from negative perception from their stakeholders. Klein and Dawar (2004) propose that being socially responsible will afford a company with an 'insurance policy' to counter negative events with bankers, investors, customers and employees. A good image and positive reputation will give a company the competitive edge from having achieved legitimacy in the eyes of its stakeholders. The social, economic and human dimensions of social responsibility can help build the reputation of a company (Saeed \& Arshad, 2012).

Better reputation will in turn increase investors' confidence and willingness to pump in more money into the business. In other words, social responsibility can indirectly enhance a company's long-term economic development and sustainability. There are a few studies that empirically found strong link between social responsibility and a company financial performance (see Orlitzky et al., 2003; McWilliams and Seigel, 2001). 
Being socially responsible means a company prioritizes on the intangibles such as the human capital, the business network, trust and reciprocity among members of the organization. According to Bowman and Ambrosini (2000), the intangible resources are rare, difficult to imitate and valuable, but can contribute towards increasing organizational performance and building stronger competitive advantage.

\subsection{The Study Hypotheses}

This study draws upon the literature review discussed above as a base for its hypothesis development below because literature search found very limited tourism and hospitality sources that focused on the link between dimensions of social responsibility (economic, environmental, human, technological and social) on dimensions of competitive advantage dimensions (low cost advantage, flexibility, delivery, distinction and innovation)

H1: There is no statistically significant impact of social responsibility dimensions on the competitive advantage of hotels in ASEZ.

$\mathrm{H} 2$ : There is no statistically significant impact of social responsibility dimensions on the low cost dimension of competitive advantage of hotels in ASEZ.

H3: There is no statistically significant impact of social responsibility dimensions on the flexibility dimension of competitive advantage of hotels in ASEZ.

H4: There is no statistically significant impact of social responsibility dimensions on the delivery dimension of competitive advantage of hotels in ASEZ.

H5: There is no statistically significant impact of social responsibility dimensions on the innovation dimension of competitive advantage of hotels in ASEZ.

H6: There is no statistically significant impact of social responsibility dimensions on the distinction dimension of competitive advantage of hotels in ASEZ.

For the purpose of this study, the independent variable i.e. the Social Responsibility is defined as a collection of decisions and actions made by the organization to achieve its desired goals and prevailing society values which in turn represent a part of the direct economic benefits for the organization's management that seeks to achieve as a part of its strategy. The dependent variable i.e. Competitive Advantage is defined as a dynamic concept that depends on self effort, innovation and adding new features perceived by clients in terms of products or the company.

\begin{tabular}{|c|c|}
\hline Social responsibility & Competitive advantage \\
\hline $\begin{array}{ll}\text { - } & \text { Economic dimension. } \\
\text { - } & \text { Environmental dimension. } \\
\text { - } & \text { Human dimension. } \\
\text { - } & \text { Technological dimension. } \\
\text { - } & \text { Social dimension. }\end{array}$ & $\begin{array}{ll}\text { - } & \text { Lower cost advantage. } \\
\text { - } & \text { Distinction advantage. } \\
\text { - } & \text { Flexibility advantage. } \\
\text { - } & \text { Delivery. } \\
\text { - } & \text { Innovation. }\end{array}$ \\
\hline
\end{tabular}

Figure1. The Study Model

\section{Methodology}

For collecting primary data, the study adopted the analytical field research methodology. It uses survey instrument and hypothesis testing to measure the perceived impact of social responsibility on the competitive advantage dimensions of the hotels in ASEZ.

The population framework of this study was hotel employees in ASEZ, which totals to about 3172 people. Sample was drawn from this population where 634 people (20 percent) from the middle management level were approached with the instrument. A total of 574 completed surveys were returned where 19 were incomplete and not included in the analysis. This gives the study a response rate of $87.5 \%$.

Middle managers were chosen as respondents for this study because it can be argued that any launching of social responsibility as a strategic activity requires strong middle managers support because they will be the one implementing the strategy. This in turn, requires employee connectedness with management vision (Kasim \& Ismail, 2012). Employees, especially the middle managers who are responsible for executing managerial vision, need to embrace the vision first and foremost before it can be properly executed. Those that are rewarded accordingly (Stone et al. 2004) 
and have been educated and trained (Kasim \& Ismail, 2012) will show commitment that will allow the organization a better chance of utilizing social responsibility to accomplish managerial goal. Indeed, a middle manager who has been conditioned to social responsibilities for example through environmental education techniques, programs and strategies, will be more disposed to execute responsible actions that will contribute towards the managerial goal of attaining competitive advantage through those actions (Filho, 1997; Bohdanowicz, 2011)

The instrument of the study was developed based upon the theoretical framework and pervious literature. The instrument consisted of several parts: The first part consists of the information that reflects the demographic characteristics of the sample such as (gender, age, education, job title, and experience). The second part consists of items that cover the independent variable (social responsibility and its dimensions). This part was designed based upon the studies of Al-Ghalibi and Ala'miri (2006), Al-Turkustani (2008), Al-Ja'afreh (2009), as well as Al-Handi and Ja'abal (2008). The researchers customized their arguments to fit the study objectives. The dimensions were the economic (items 1-6); the environmental (items 7-11); human (items 12-16); technological (items 1722) and the social dimension that was represented by items 23-27. The third part consists of the dependent variable dimension (competitive advantage) adapted from the studies of Al'adhaylih (2004) and Al-Tamire and Khashali (2004). This part consists of the following dimensions: the lower cost (item 28-32); flexibility (item 33-37); delivery (item 38-42); innovation (item 43-47) and distinction dimension which was assigned the items (item 48-52).

The researchers used Likert Scale to measure the respondents' answers upon the weighted scales where $5=$ strongly agree, $4=$ agree, $3=$ neutral, $2=$ disagree and $1=$ strongly disagree.

Five professionals and academics in the Jordanian Universities to verify its validity in terms of language and relevancy to the topic reviewed the instrument. Those experts approved the final draft of the instrument after which a pilot test on 25 people determined the stability of the instrument. Cronbach Alpha coefficient was used to assure the internal contingency and to calculate the stability coefficient for each item of the study as shown in Table 1.

Table1. Coefficients of Stability for Each Item

\begin{tabular}{|l|l|c|}
\hline Variable & Dimension & Stability Coefficient \\
\hline Social Responsibility & Economic & 0.88 \\
& Environmental & 0.86 \\
& Human & 0.89 \\
& Technological & 0.82 \\
& Social & 0.84 \\
\hline Competitive Advantage & The lower cost & 0.88 \\
& Flexibility & 0.90 \\
& Delivery & 0.86 \\
& Innovative & 0.83 \\
& Distinction & 0.85 \\
\hline Total & & $\mathbf{0 . 9 1}$ \\
\hline
\end{tabular}

The results in Table 1 showed that stability coefficients for the social responsibility dimensions ranged between $0.82-0.89$, while for the competitive advantage dimensions the range was $0.83-0.90$. The total coefficient was 0.91 . Since the accepted internal contingency is 0.60 and more, these values were considered acceptable for the study objectives.

\section{FINDINGS}

\section{Descriptive Data}

The sociodemographic profile of respondents in this study is as in Table 2 below. The majority of the respondents consist of male hotel employees with bachelor degree between the ages of 30-40 years old with 11-20 years of work experience.

Table2. Distribution of Sample in termsoOf Gender, Age, Job Title, Experience and Education

\begin{tabular}{|l|l|l|l|}
\hline Variable & Segment & Number & \% \\
\hline Education level & Secondary or less & 64 & 11.5 \\
& Diploma & 126 & 22.7 \\
& Bachelor & 272 & 49.0 \\
& Graduate & 93 & 16.8 \\
\hline Age & 30 years or less & 113 & 20.4 \\
& $30-40$ & 225 & 40.5 \\
\hline
\end{tabular}


Impact of Social Corporate Responsibility on Achieving Competitive Advantage: The Case of Hotels in the Aqaba Special Economic Zone (ASEZ), Jordan

\begin{tabular}{|l|l|l|l|}
\hline & $41-50$ & 145 & 26.1 \\
& $51-$ more & 72 & 13.0 \\
\hline Experience & 10 years or less & 99 & 17.8 \\
& $11-20$ & 166 & 29.9 \\
& $21-30$ & 159 & 28.6 \\
& $31-$ more & 131 & 23.6 \\
\hline Gender & Male & 461 & 83.1 \\
& Female & 94 & 16.9 \\
\hline Job title & Manager & 24 & 4.3 \\
& Deputy Manager & 37 & 6.7 \\
& Supervisor & 58 & 10.5 \\
& Branch Head & 95 & 17.1 \\
& Assistant supervisors / group leaders & 341 & 61.4 \\
\hline
\end{tabular}

Before proceeding with the hypothesis testing, data was tested for fitness. To check for multicollinearity, the researchers run the variance inflation factor (VIF) and tested the permitted variance for each variable. Referring to Table 3, the rule is that if VIF for the variable $>10$ and the tolerance of variance $<0.05$, then the variable has correlation with other independent variables, which will lead to problem in analysing the regression. For the study's data, the VIF value for all variables was $<10$ (ranging between 2.789-5.102 while the tolerance value was $>0.05$ (ranging between 0.395-0.287). Therefore there is no real problem with multi-collinearity of the data.

Table3. Test of VIF, or Tolerance and Skewness

\begin{tabular}{|l|l|l|l|}
\hline Dimensions of Independent Variable & Tolerance & VIF & Skewness \\
\hline Economic dimension & 0.395 & 3.119 & 0.211 \\
\hline Environmental dimension & 0.374 & 3.491 & 0.209 \\
\hline Human dimension & 0.287 & 5.102 & 0.129 \\
\hline Technological dimension & 0.381 & 2.789 & 0.347 \\
\hline Social dimension & 0.326 & 3.891 & 0.259 \\
\hline
\end{tabular}

To verify the assumption of normal distribution of data the researchers depended on the skewness coefficient, where it shows that there was no problem related to the normal distribution of study data. Table 4 below shows the validity of testing model for hypothesis, where $\mathrm{F}$ calculated value was $>\mathrm{F}$ tabular value $(\alpha \leq 0.05)$, the dimensions of social responsibility explained $54 \%$ of the variance in the competitive advantage, as well as explaining $44.3 \%$ of the variance in the lower cost dimension, $42.4 \%$ of variance in the flexibility dimension, $43.7 \%$ in the delivery dimension, $41.1 \%$ in the innovation dimension and $59.3 \%$ of the variance in the distinction dimension of competitive advantage. Therefore the model can be assumed as valid in testing the hypotheses.

Table4. Results of Regression Analysis of Variance to Assume the Validity of Model to Test the Hypothesis

\begin{tabular}{|c|c|c|c|c|c|c|}
\hline Dependent Variable & Source & $\mathbf{R}^{2}$ & $\Sigma \mathbf{s q}$ & Mean of sq & Calc. & Sig. level \\
\hline \multirow[b]{2}{*}{ Competitive advantage } & Reg. & \multirow[b]{2}{*}{0.54} & 376.088 & 75.218 & \multirow[b]{2}{*}{$128.965 *$} & \multirow[b]{2}{*}{0.000} \\
\hline & Error & & 320.198 & 0.583 & & \\
\hline \multirow[b]{2}{*}{ The lower cost } & Reg. & \multirow[b]{2}{*}{0.443} & 382.105 & 76.421 & \multirow[b]{2}{*}{$87.279 *$} & \multirow[b]{2}{*}{0.000} \\
\hline & Error & & 480.646 & 0.875 & & \\
\hline \multirow[b]{2}{*}{ Flexibility } & Reg. & \multirow[b]{2}{*}{0.424} & 374.281 & 74.856 & \multirow[b]{2}{*}{$80.815^{*}$} & \multirow[b]{2}{*}{0.000} \\
\hline & Error & & 508.519 & 0.926 & & \\
\hline \multirow[b]{2}{*}{ Delivery } & Reg. & \multirow[b]{2}{*}{0.437} & 391.265 & 78.253 & \multirow[b]{2}{*}{$85.217 *$} & \multirow[b]{2}{*}{0.000} \\
\hline & Error & & 504.135 & 0.918 & & \\
\hline \multirow[b]{2}{*}{ Innovation } & Reg. & \multirow[b]{2}{*}{0.411} & 372.382 & 74.476 & \multirow[b]{2}{*}{$76.503^{*}$} & \multirow[b]{2}{*}{0.000} \\
\hline & Error & & 534.453 & 0.974 & & \\
\hline \multirow[b]{2}{*}{ Distinguishment } & Reg. & \multirow[b]{2}{*}{0.593} & 469.842 & 93.968 & \multirow[b]{2}{*}{$143.760 *$} & \multirow[b]{2}{*}{0.000} \\
\hline & Error & & 68.080 & 0.124 & & \\
\hline
\end{tabular}

* Statistically significant at $\alpha \leq 0.05$

\section{TEST OF HYPOTHESIS}

Ho1: There is no statistically significant impact of social responsibility dimensions i.e. economic, environmental, human, technological and social on competitive advantage. 
Table 5 shows that four of the five social responsibility dimensions (economic, environmental, human, and technological) have an impact on the competitive advantage variable where calculated $t$ values $1.552,2.667,3.910$ and 4.423 respectively were significant at $\alpha \leq 0.05$ while Beta values were $0.148,0.232,0.249$ and 0.391 respectively. The standard errors were $0.065,0.100,0.085$ and 0.102 while B values were $0.296,0.286,0.271$ and 0.450 respectively.

Table5. Results of Regression Analysis of Variance on the Social Responsibility Dimensions

\begin{tabular}{|l|c|c|c|c|c|}
\hline Dimensions of ocial Responsibility & B & Std. Error & Beta & Calculate T & Sig.Level t* \\
\hline Economic & 0.296 & 0.065 & 0.148 & $1.552^{*}$ & 0.000 \\
\hline Environmental & 0.268 & 0.100 & 0.232 & $2.667 *$ & 0.008 \\
\hline Human & 0.271 & 0.085 & 0.249 & $3.190^{*}$ & 0.002 \\
\hline Technological & 0.450 & 0.102 & 0.391 & $4.423^{*}$ & 0.000 \\
\hline Social & 0.200 & 0.103 & 0.174 & $1.953^{* *}$ & 0.051 \\
\hline
\end{tabular}

* Statistically significant at $\alpha \leq 0.05$

** Statistically insignificant at $\alpha \leq 0.05$

On the other hand, there is no impact of the social dimension of social responsibility on competitive advantage, where calculated value of $t$ was 1.953 , which is statistically insignificant at $\alpha \leq 0.05$. These results show that the null hypothesis is partially supported because the economic, environmental, human, and technological dimensions of social responsibility do have an impact on competitive advantage. However, the social dimension does not.

Table6. Results of Stepwise Multiple Regression (SMR)

\begin{tabular}{|l|c|c|c|}
\hline Rank of dimension in forecasting equation & $\mathbf{R}^{2}$ & Calculated t value & Sign. Level t* \\
\hline Economic & 0.483 & 6.794 & 0.000 \\
\hline Technological & 0.522 & 5.340 & 0.000 \\
\hline Human & 0.533 & 3.673 & 0.000 \\
\hline Environmental & 0.537 & 2.963 & 0.000 \\
\hline
\end{tabular}

* Statistically significant at $\alpha \leq 0.05$

Stepwise multiple regression (SMR) to determine dimension that has the most effect on competitive advantage showed that the economic dimension explained $48.3 \%$ of variance in the dependent variable. Meanwhile, the technological dimension explained $52.2 \%$ of the variance, the human dimension explained $53.3 \%$ of the variance and the environmental dimension explained $53.7 \%$ of variance in the competitive advantage. Therefore it can be concluded that the environmental dimension of social responsibility affects competitive advantage the most.

Ho2: There is no statistically significant impact, at $\alpha \leq 0.05$, of social responsibility dimensions on the Lower cost dimension of competitive advantage.

In terms of the impact of social responsibility dimensions on the Lower cost dimension of competitive advantage, Table 7 below indicates that all the social responsibility dimensions have impacts on the Lower cost dimension of competitive advantage. The calculated $t$ values of $4.958 ; 2.213 ; 2.280$ and 2.834 respectively were significant at $\alpha \leq 0.05$. The values of Beta were $0.178 ; 0.196 ; 0.468$ and 0.277 respectively and the standard errors were $0.080 ; 0.104 ; 0.125$ and 0.126 respectively. Meanwhile $\beta$ values were $0.397 ; 0.237 ; 0.599$ and 0.356 respectively. Therefore these results do not support the null hypothesis because all dimensions of the social responsibility do have an impact on the Lower cost dimension of competitive advantage.

Table7. Results of Regression Analysis of Variance on the Lower Cost Dimension of Competitive Advantage

\begin{tabular}{|l|l|l|l|l|l|}
\hline Dimensions of social responsibility & B & Std. error & Beta & Calc. t value & t Sig. level \\
\hline Economic & 0.397 & 0.080 & 0.178 & $4.958^{*}$ & 0.000 \\
\hline Environmental & 0.272 & 0.123 & 0.212 & $2.213^{*}$ & 0.027 \\
\hline Human & 0.237 & 0.104 & 0.196 & $2.280^{*}$ & 0.023 \\
\hline Technological & 0.599 & 0.125 & 0.468 & $4.802^{*}$ & 0.000 \\
\hline Social & 0.356 & 0.126 & 0.277 & $2.834^{*}$ & 0.005 \\
\hline
\end{tabular}

* Statistically significant at $\alpha \leq 0.05$

SMR analysis (Table 8 below) indicates that the economic dimension explained $37.9 \%$ of the variance in the dependent variable. The technological dimension explained $40.8 \%$ of the variance, 
Impact of Social Corporate Responsibility on Achieving Competitive Advantage: The Case of Hotels in the Aqaba Special Economic Zone (ASEZ), Jordan

while the social dimension explained $42.6 \%$ of the variance. The human dimension explained $42.9 \%$ of the variance in the lower cost dimension of competitive advantage. This shows that the human dimension of social responsibility affects the Lower cost dimension of competitive advantage the most.

Table8. Results of SMR for Forecasting the Lower Cost Advantage through Social Responsibility Dimensions as Independent Variables

\begin{tabular}{|l|l|l|l|}
\hline $\begin{array}{l}\text { Ranking of independent variables entry in } \\
\text { forecasting }\end{array}$ & R2 coefficient & t Calculated value & t Sig. level \\
\hline Economic dimension & 0.379 & $6.189^{*}$ & 0.000 \\
\hline Technological dimension & 0.408 & $5.802^{*}$ & 0.000 \\
\hline Social dimension & 0.426 & $3.834^{*}$ & 0.000 \\
\hline Human dimension & 0.429 & $3.280^{*}$ & 0.005 \\
\hline
\end{tabular}

* Statistically significant at $\alpha \leq 0.05$

Ho3: There is no statistically significant impact of social responsibility dimensions on the Flexibility dimension of competitive advantage.

The results in Table 9 below indicate that there is significant impact of the economic, environmental, human, technological and social dimensions of social responsibility on the Flexibility dimension of competitive advantage. This means the null hypothesis is not supported.

Table9. Results of Regression Analysis of Variance on the Flexibility Advantage

\begin{tabular}{|l|l|l|l|l|l|}
\hline Social responsibility Dimensions & B & Std. error & Beta & Calc. t value & t Sig. level \\
\hline Economic dimension & 0.413 & 0.082 & 0.183 & $5.010^{*}$ & 0.000 \\
\hline Environmental dimension & 0.254 & 0.127 & 0.196 & $2.011^{*}$ & 0.045 \\
\hline Human dimension & 0.276 & 0.107 & 0.226 & $2.583^{*}$ & 0.010 \\
\hline Technological dimension & 0.539 & 0.128 & 0.416 & $4.197^{*}$ & 0.000 \\
\hline Social & 0.331 & 0.129 & 0.254 & $2.558^{*}$ & 0.011 \\
\hline
\end{tabular}

* Statistically significant at $\alpha \leq 0.05$

The SMR analysis as shown in Table 10 below indicates that the economic dimension explained $35.6 \%$ of the variance in the Flexibility dimension of competitive advantage, while the technological dimension explained $41 \%$ of this variance, followed by the human dimension which explained $41.6 \%$ of the variance, and the social dimension explained $42 \%$ of the variance. The environmental dimension explained $42.4 \%$ of the variance in the Flexibility dimension of the dependent variable. Thus the environmental dimension of social responsibility has the most effect on the Flexibility dimension of competitive advantage.

Table10. Results of SMRfFor Forecasting the Flexibility Advantage through Social Responsibility Dimensions as Independent Variables

\begin{tabular}{|l|l|l|l|}
\hline $\begin{array}{l}\text { Ranking of dimensions of social responsibility in } \\
\text { Forecasting equation }\end{array}$ & $\mathbf{R 2}$ coefficient & t Calculated value & $\mathbf{t}^{*}$ Sig. level \\
\hline Economic dimension & 0.356 & $5.986^{*}$ & 0,000 \\
\hline Technological dimension & 0.410 & $4.986^{*}$ & 0,000 \\
\hline Human dimension & 0.416 & $3.152^{*}$ & 0,000 \\
\hline Social dimension & 0.420 & $2.998^{*}$ & 0,004 \\
\hline Environmental dimension & 0.424 & $2.659^{*}$ & 0,012 \\
\hline
\end{tabular}

* Statistically significant at $(\alpha \leq 0.05)$

Ho4: There is no statistically significant impact of social responsibility dimensions on the Delivery dimension of competitive advantage.

Table 11 below shows that all dimensions of social responsibility do have significant impact on the Delivery dimension of competitive advantage. The values of Beta for the variables were $0.197 ; 0.215$; $0.232 ; 0.454$ and 0.323 respectively where standard errors were $0.082 ; 0.082 ; 0.126 ; 0.106 ; 0.128$; and 0.129 respectively. The values of $\beta$ test were $0.449 ; 0.281 ; 0.285 ; 0.592$; and 0.423 respectively. These results do not support the null hypothesis (Ho4). 
Table11. Results of Regression Analysis of Variance on the Delivery Dimension of Competitive Advantage

\begin{tabular}{|l|l|l|l|l|l|}
\hline Social responsibility Dimensions & B & Std. error & Beta & Calc. t value & t Sig.* level \\
\hline Economic dimension & 0.449 & 0.082 & 0.197 & $5.476^{*}$ & 0.000 \\
\hline Environmental dimension & 0.281 & 0.126 & 0.215 & $2.228^{*}$ & 0.026 \\
\hline Human dimension & 0.285 & 0.106 & 0.232 & $2.681^{*}$ & 0.008 \\
\hline Technological dimension & 0.592 & 0.128 & 0.454 & $4.635^{*}$ & 0.000 \\
\hline Social & 0.423 & 0.129 & 0.323 & $3.286^{*}$ & 0.001 \\
\hline
\end{tabular}

* Statistically significant at $\alpha \leq 0.05$

The SMR analysis to determine the affecting independent variables in the delivery dimension (Table 12) shows that the economic variable affected the delivery dimension of competitive advantage and explained $35.7 \%$ of the variance. The technological variable explained $42 \%$ of the variance; the social variable explained $42.4 \%$ of variance; the human variable explained $43.2 \%$ of variance, while the environmental variable explained $43.7 \%$ of the variance along with other independent variables. This shows that the environmental dimensions of social responsibility affect the Delivery dimension of competitive advantage

Table12. Results of SMR Analysis for Forecasting the Delivery Dimension Advantage through Independent Variables of Social Responsibility

\begin{tabular}{|l|l|l|l|}
\hline $\begin{array}{l}\text { Ranking of dimensions of social responsibility } \\
\text { in forecasting equation }\end{array}$ & R2 coefficient & t Calculated value & t Sig.* level \\
\hline Economic dimension & 0.357 & $6.269^{*}$ & 0.000 \\
\hline Technological dimension & 0.420 & $5.273^{*}$ & 0.000 \\
\hline Social dimension & 0.424 & $4.157^{*}$ & 0.000 \\
\hline Human dimension & 0.432 & $3.083^{*}$ & 0.000 \\
\hline Environmental dimension & 0.437 & $2.761^{*}$ & 0.010 \\
\hline
\end{tabular}

* Statistically significant at $\alpha \leq 0.05$

Ho5: There is no statistically significant impact of independent variables of social responsibility on the Innovation dimension of competitive advantage.

Table 13shows that all dimensions of social responsibility do have statistically significant impact on the Innovation dimension of competitive advantage. The values of Beta were $0.173 ; 0.208 ; 0.245$; 0.383 ; and 0.260 respectively, while the standard error values were $0.084 ; 0.130 ; 0.110 ; 0.132$; and 0.133 respectively. $\beta$ values were $0.397 ; 0.274 ; 0.3-4 ; 0.503$; and 0.342 respectively. These results indicate that the null hypothesis above is not supported.

Table13. Results of Regression Analysis of Variance on the Innovation Dimension of Competitive Advantage

\begin{tabular}{|l|l|l|l|l|l|}
\hline Social responsibility Dimensions & B & Std. error & Beta & Calc.t value & t Sig.* level \\
\hline Economic dimension & 0397 & 0.084 & 0.173 & $4.702^{*}$ & 0.000 \\
\hline Environmental dimension & 0.274 & 0.130 & 0.208 & $2.115^{*}$ & 0.035 \\
\hline Human dimension & 0.304 & 0.110 & 0.245 & $2.769^{*}$ & 0.006 \\
\hline Technological dimension & 0.503 & 0.132 & 0.383 & $3.825^{*}$ & 0.000 \\
\hline Social & 0.342 & 0.133 & 0.260 & $2.584^{*}$ & 0.010 \\
\hline
\end{tabular}

* Statistically significant at $\alpha \leq 0.05$

SMR analysis to determine the most affecting independent variables on the Innovation dimension of competitive advantage shows that the economic dimension of social responsibility explained $38.4 \%$ of the variance, while the technological variable explained $37.4 \%$, the human explained $40.2 \%$ of the variance, and the social explained $40.6 \%$, whereas the environmental variable explained $41.1 \%$ of the variance (see Table 14 below). This means that environmental dimension of social responsibility has the most affect on the Innovation dimension of competitive advantage.

Table14. Results of SMR Analysis to Forecasting the Innovation Advantage through Social Responsibility Dimensions

\begin{tabular}{|l|l|l|l|}
\hline Independent variables of social responsibility & R2 coefficient & t Calculated value & t Sig.* level \\
\hline Economic dimension & 0.384 & $5.892^{*}$ & 0.000 \\
\hline Technological dimension & 0.374 & $4.298^{*}$ & 0.000 \\
\hline Human dimension & 0.402 & $3.269^{*}$ & 0.000 \\
\hline Social dimension & 0.406 & $2.894^{*}$ & 0.001 \\
\hline Environmental dimension & 0.411 & $2.743^{*}$ & 0.013 \\
\hline
\end{tabular}

* Statistically significant at $(\alpha \leq 0.05)$ 
Ho6: There is no statistically significant impact of the social responsibility variables on the Distinction dimension of competitive advantage.

The results in Table 15 below shows that all but one of the social responsibility dimensions has a statistically significant impact on the Distinction dimension of competitive advantage. The Beta values were $0.444 ; 0.263 ; 0.259$; and 0.254 respectively. The standard error values were $0.047 ; 0.047$; $0.039 ; 0.030 ;$ and 0.046 respectively. $\beta$ values were $0.451 ; 0.019 ; 0.251 ; 0.248$; and -.237 respectively. This means the null hypothesis is partially supported because the environmental dimension of social responsibility does not have a statistically significant impact on the distinction dimension of competitive advantage.

Table15. Results of Regression Analysis of Variance on the Distinction Advantage

\begin{tabular}{|l|l|l|l|l|l|}
\hline $\begin{array}{l}\text { Social } \\
\text { variables }\end{array}$ & Besponsibility & B & Calc.t value & t Sig.* level \\
\hline Economic dimension & 0.451 & 0.047 & 0.444 & $9.530^{*}$ & 0.000 \\
\hline Environmental dimension & 0.019 & 0.047 & 0.018 & $0.398^{* *}$ & 0.691 \\
\hline Human dimension & 0.251 & 0.039 & 0.263 & $6.425^{*}$ & 0.000 \\
\hline Technological dimension & 0.248 & 0.030 & 0.259 & $5.582^{*}$ & 0.000 \\
\hline Social & 0.237 & 0.046 & 0.254 & $5.559^{*}$ & 0.000 \\
\hline
\end{tabular}

* Statistically significant at $\alpha \leq 0.05$

** Statistically insignificant at $\alpha \leq 0.05$

The results indicated that the environmental dimension of social responsibility has no impact on the Distinction dimension of competitive advantage, where $t$ calculated value was statistically insignificant at $\alpha \leq 0.05$. These results indicate that the null hypothesis above is partially supported.

The SMR analysis found the economic dimension of the independent variable explained $49.6 \%$ of the variance in the Distinction dimension of the dependent variable. The human dimension explained $56.9 \%$ of that variance, while the technological dimension explained $58.1 \%$ of the variance. The social variable explained $59.1 \%$ of the variance in the distinction dimension of competitive advantage. This indicates that the social dimension of social responsibility affects the Distinction dimension of competitive advantage the most.

Table16. SMR Analysis Results to Forecast the Advantage of Distinction through the Social Responsibility Dimensions as Independent Variables

\begin{tabular}{|l|l|l|l|}
\hline $\begin{array}{l}\text { Entry of independent variables in the } \\
\text { forecast equation }\end{array}$ & R2 coefficient & t Calculated value & t Sig.* level \\
\hline Economic dimension & 0.496 & $10.852^{*}$ & 0.000 \\
\hline Human dimension & 0.569 & $7.762^{*}$ & 0.000 \\
\hline Technological dimension & 0.581 & $6.631^{*}$ & 0.000 \\
\hline Social dimension & 0.591 & $6.030^{*}$ & 0.000 \\
\hline
\end{tabular}

* Statistically significant at $\alpha \leq 0.05$

\section{DisCUSSIONS}

The analysis have shown that within the ASEZ hotels context, the dimensions of social responsibility explained 54\% of the variance in the competitive advantage in addition to explaining the variability in the dimensions of competitive advantage. This indicates a perceived importance of social responsibility as a change factor in ASEZ hotels' sustained existence, which shows that the service sector in Jordan is also embracing the concept of social responsibility just like the non-service sector as found by researchers such as Zuriekat (2011), Al-Turkustani (2008), Al-Jaiafrih (2009) and AlGhalibi and Ala'aniri (2008).

The SMR analysis results also indicated that all dimensions of social responsibility consistently have effects on lower cost, flexibility, delivery and distinction dimensions of competitive advantage in varying degrees. However, social dimension was found to have no effect on competitive advantage. In contrast, certain dimensions affect the dependent variable the most. For example, environmental dimension has the most effect on competitive advantage. Meanwhile the human dimension of social responsibility was found to affect the lower cost dimension of competitive advantage, the 
environmental dimension of social responsibility has the most effect on the flexibility, delivery, and innovation dimensions of competitive advantage while the social dimension of social responsibility affects the distinction dimension of competitive advantage. This means, hotels that show social responsibility by focusing on the environmental dimension (either via providing unique and innovative green product or protection of the environment, and improvement of the environmental conditions and environmental problems) have the most competitive advantage.

\section{Managerial Implications}

Overall, the study found that all dimensions of social responsibility have significant impact on the lower cost dimension of competitive advantage. From managerial perspective, this result indicates that employing social responsibility allows hotels in ASEZ to achieve lower cost dimension of competitive advantage. This result is expected because lower cost strategies (for example through cost or resource savings) can make business become more competitive due to the ability to invest the unused revenues in other more important areas such as corporate communication and public relations. It can also enable hotels to provide values to customer through low price offers and other special promotions. In the long run, hotels can benefit from enhanced public image as value for money providers.

The results showed that while all dimensions of social responsibility affect the flexibility, delivery and innovation dimensions of competitive advantage, the environmental dimension of social responsibility (i.e. by providing a respectful and responsible working environment and/or by protecting or improving the natural environment through product innovation) have high variance explained for all the three dimensions. From managerial standpoint this means that improving the environmental dimension of social responsibility in hotel would enable hotels to: 1) offer flexibility in order to fulfil the needs of customers, ultimately acquiring customer trust and making hotels become more competitive. Being flexible means hotels will seek to develop and improve their work procedures continuously so that their clients can feel happy, satisfied and safe to trust them; 2) ensure delivery care which will ultimately lead to the improvement of its competitive advantage. Efficient delivery of products and services can contribute to customers' overall satisfaction level during their hotel stay and ultimately improve the respective hotel's competitiveness; and 3) generate a democratic working context that stimulate idea generation which can lead to innovativeness. Since innovation is key to progress, innovative ideas will make a hotel more competitive. In addition, it can lead to better discussion and interactions between top management, lower management and staff, so that cooperation between individuals and management can be enhanced.

Except for the environmental dimension, social responsibility dimensions were also found to impact the distinction dimension of ASEZ hotels' competitive advantage. Enhancing the social dimension of social responsibility (such as offering high quality services, healthy and safe products, prioritizing consumer rights ethical marketing, and providing justice and equity to stakeholders) in particular, will help hotels achieve distinction in the eye of their customers and become more competitive. This may occur through activities such as providing facilities of entertainment and care of client, ensuring short waiting period, applying a computerized system to serve clients as well as employing an appropriate number of staff to meet the needs of client.

\section{Implications}

Though this study does not offer any theoretical or methodological contribution to the wider body of knowledge, the above results do provide empirical support the connection between social responsibility and competitive advantage by showing that the relationship between the concepts can also be empirically proven within the context of hotel industry in a developing country. In terms of managerial implications, the study results show that since awareness and acceptance of modern management approach is evident in the context of ASEZ, Jordan, ASEZ hotels must evolve their management philosophies and practices to reflect this changing awareness and acceptance and ultimately to become more competitive in the local and global platforms. Therefore, it is recommended that hotel practitioners in ASEZ take the following actions in order to become more socially responsible: Firstly, ASEZ hotels must include social responsibility as one of their corporate objectives. Since top management commitment is an important driver of corporate social responsibility (Kasim, 2007), having social responsibility as one of corporate objectives will enable inculcation of working culture that will assist hotel in achieving that objective (Kasim, 2009). 
Secondly, as non-regulatory pressure from sources such as trade associations is also an important driver for corporate social responsibility (see Kasim, 2006), hotel trade association in ASEZ region can encourage hotels to start building an organizational culture within their respective organizations. They may develop strategies that motivate workers and pay attention to workers' interests to encourage behaviours that will support their social responsibility objectives.

Thirdly, ASEZ hotels can strive to conform with local society's values and ethical expectation in terms of human rights, law, corruption, disclosure and transparency. The reason is that philanthropic activities and competitive advantage can become mutually reinforcing since corporate philanthropy may be used to influence and allow the organization to improve its competitiveness and the needs of its stakeholders as well (Porter and Kramer, 2002)

Admittedly, these values and expectations may be so diverse that hotels may found them overwhelming. However, hotels must start small and gradually develop their compliance, based on what matter most to the local society their hotel operates in. For example, hotels can first adhere to society's expectation for a clean and pollution-free local environment via activities such as collectively contributing to the cleaning up of local attractions such as the Dead Sea, Wadi Rum and Petra. This may lessen the burden of the local authority and make those destinations more attractive to both local and international tourists. Progressively, ASEZ hotels may tackle bigger issues such as water or poverty.

Lastly, as business companies build a competitive advantage by engaging in those CSR initiatives that meet 'the perceived demands of stakeholders'(Kurucz et al.2008, p. 89), ASEZ hotels may also want to be socially responsible by including local community as important stakeholders and addressing their issues and concerns. This entails effort to gauge those issues and concerns via consultation or research. ASEZ hotels may also want to engage in educating local community about cleanliness, the importance of recycling and other environmental issues. As a business that operates in a developing country where environmental consciousness may still be embryonic, ASEZ hotels can show leadership by reaching to local community in environmental education within the context of tourism. Conferences and workshops by the hotels at ASEZ are possible means of communication with people and media to show hotels responsible activities and project, of their services and charity investments, besides getting the feedback from people about their initiatives.

Further studies on this topic may aim to fill knowledge gap on ASEZ local governmental and community expectations of hotels in terms of social responsibility. As regulatory and non-regulatory pressures (from community, nongovernmental organizations) have been found in the literature as one of corporate social responsibility primary drivers (see Kasim, 2009), then this understanding can further guide hotel practitioners in ASEZ in deciding aspects of social responsibility they should implement in their respective hotels.

\section{REFERENCES}

[1] Aladhaylih, J. (2004): The Impact of Strategic Options on the Completive Advantage of Arab Potash Company, Unpublished Master Thesis, Mu'tah University, Karak, Jordan.

[2] Al-Ghalibi, T. M, \& Al-Amri S. M (2008): The Social Responsibility and Business Ethics: Business and Society. 2nd ed. Dar Wael for Publishing and Distributions.. Amman.

[3] Al-Hamd F. M. \& Ja'abal M. M. (2008): The Extent of Director Perception of the Social Responsibility Concept and Accompanying Activities: An analytical study of the working directors in a sample of industrial organizations in Yemen. Published by the Faculty of Administrative Sciences, Thamar University.

[4] Al-Hammori, S. (2010): Social Responsibility Between Theory and Practice Excellent in Corporate Development. Retrieved on July 29, 2012 from website: CSR @excellence inc.org

[5] Al-Ja'afrah, A. F. (2009): The Impact of Business Ethics and Social Responsibility on the Strategic Components of Banks in Jordan: Published by the Faculty of Higher Financial Studies, Amman Arab University, Jordan.

[6] Al-Qura'n, A. Z. F. (2007): The Influence of Manufacturing Elasticity on the Competitive Advantage: A field study on the furniture Manufacturing Companies of King Abduallh Industrial Zone-Sahab, Unpublished Master Thesis, Jordan University, Amman. 
[7] Al-Rubaiei, L. (2010): The Ethics of Marketing and Social Responsibility, Dar Wael for Publishing and Distributions, Amman, Jordan.

[8] Al-Tamimi, I. F. \& Al-Khashli S. J. (2004): The Innovative Behavior and its Impact on the Competitive Advantage in the food industry in Jordan; Al Basair Review. 8(2): 84-111.

[9] Al-Turkustani, H. (2008): The Extent of Adopting Social Responsibility by the Private Sector Managements; An exploratory field study on the Saudi Companies; Unpublished Master Thesis, University of King Abdul Aziz, Jeddah.

[10] Annadi, F. (2008): The Social Responsibility of the Management in the Developing Countries and its Role in Growing the Innovative Capabilities of Employees (A case study for Egypt), Review of the Federation of Administrative Development Society, 45(3): 35-58.

[11] Anselmsson, J., \& Johansson, U. (2007): Corporate Social Responsibility and the Positioning of grocery brands: An exploratory study of retailer and manufacturer brands at point of purchase. International Journal of Retail \& Distribution Management, 35(10): 835-856

[12] Ashishani, A. \& Sharafuddin, T. (2009): The Role of IT and Advanced Telecom Technology in Acquisition of Competitive Advantage, A field study on Jordan Mobilcom, Unpublished Ph. D Dissertation, Amman Arab University, Jordan.

[13] Azzuraiqat, K. (2011): The Impact of Strategic Orientation on Achieving the Social responsibility: An applied study on the commercial Jordanian banks, Review of Baghdad College for Economic Sciences. 34(3): 58-76.

[14] Barahmah, M. M. A. (2007): The Strategic Option and its Influence on Achieving the Competitive Advantage for the Corporate: a field study on the pharmaceutical industry in Yemen, Unpublished Masters Thesis, Aden University, Yemen.

[15] Bowman, C. \& Ambrosini, V. (2000) Value creation versus value capture: Towards a coherent definition of value in strategy. British Journal of Management 11(1): 1-15.

[16] Carrigan, M, \& Attalla, A. (2001), The myth of the ethical consumer - do ethics matter in purchase behavior?, Journal of Consumer Marketing. 18(7): 560-77

[17] Carroll, A.B. \& Shabana, K.M. (2010) The business case for corporate social responsibility: a review of concepts, research and practice. International Journal of Management Reviews. Vol(num): pp85-105. DOI: 10.1111/j.1468-2370.2009.00275.x

[18] Dasi, W. H. (2007): The Role of Knowledge Management in achieving the Competitive Advantage: An applied study on the public Syrian banking, Unpublished Master Thesis, University of Damascus, Syria.

[19] Eliashberg, J. \& Stienberg R. (1991): Competitive Strategies for tow firms with Asymmetric production cost structure. Management Science. 37(11): 1452-1473.

[20] Eweje,G. \& Bentley,T. (2006).CSR and staff retention in New Zealand companies: A literature review. Department of Management and International Business Research Working Paper series 2006, No.6, Auckland, NZ: Massey University. Retrieved on Sepetember 14, 2012 from http://hdl.handle.net/10179/635

[21] Ismael, M. I. A., (2009): The Impact of Using IT on Achieving the Competitive Advantage Strategies: A field study on pharmaceutical industry in Jordan, Unpublished Doctoral Dissertation, Amman Arab University.

[22] Jones, G. \& Heil C. (2001): The Strategic Management. Translated by Rifai, Mohammad Rifai and Abdul Mota'al, Mohammad S. Ahmad, 4th edition, first volume, Dar Al-Marrekh Publications, Riyadh, Saudi Arabia.

[23] Kasim, A., (2009). Towards a wider adoption of business responsibility in the hotel sector. International Journal of Hospitality and Tourism. Administration 8(2):25-49. DOI: 10.1300/ J149v08n02_02.

[24] Kasim, A. (2007). Corporate environmentalism in the hotel sector: evidence of drivers and barriers in Penang, Malaysia. Journal of Sustainable Tourism, 15(6), 680-699

[25] Kasim, A. (2006). The need for environmental and social responsibility in the tourism industry. International Journal of Hospitality and Environmental Management, 7(1), 1-22.

[26] Kasim, A. \& Ismail, A. (2012). Environmentally friendly practices among restaurants: Drivers and barriers to change. Journal of Sustainable Tourism 20 (4), 551-570 
[27] Klein, J. and Dawar, N. (2004) Corporate social responsibility and consumers' attributions and brand evaluations in product-harm crisis. International Journal of Research in Marketing 21(3): 203-217

[28] Kurucz, E., Colbert, B. and Wheeler, D. (2008). The busi-ness case for corporate social responsibility. In Crane, A., McWilliams, A., Matten, D., Moon, J. and Siegel, D.(eds), The Oxford Handbook of Corporate Social Responsibility. Oxford: Oxford University Press, pp. 83-112.

[29] Mcgregor, E.B. (1994): Public Service Status Review: The Excellence Agenda, Public Administration, 54(3): (May/June 1994), 296--- 301. Book Review of Patricia Ingraham and Donald Kettl, Agenda for Excellence: Public Service in America (1992).

[30] McWilliams, A. and Siegel, D. (2001) Corporate social responsibility: A theory of the firm perspective. Academy of Management Review 26(1): 117-127.

[31] Orlitzky, M., Schmidt, F. and Rynes, S. (2003) Corporate social and financial performance: A meta-analysis. Organization Studies 24(3): 403-411.

[32] Porter, M. E. (1980). Competitive Strategy. Free Press , New York .

[33] Porter, M.E. \& Kramer, M.R. (2002). The competitiveadvantage of corporate philanthropy. Harvard Business Review, 80: 56-69

[34] Powell , T. C. (2009). Total Quality Management as competitive advantage: Review and empirical study. Strategic Management. 16: 15-37.

[35] Reuter, C., Foerstl, K., Hartmann, E., \& Blome, C. (2010). Sustainable global supplier management: The role of dynamic capabilities in achieving competitive advantage, The Journal of Supply Chain Management, 46(2): 45-63.

[36] Saeed, M.M. \& Arshad, F. (2012). Corporate social responsibility as a source of competitive advantage: The mediating role of social capital and reputational capital. Journal of Database Marketing \& Customer Strategy Management (2012) 19, 219-232. doi:10.1057/dbm.2012.19

[37] Sharma M., \& Kodali R. (2008), Development of a framework for manufacturing excellence, Measuring Business Excellence, 12(4):50 - 66

[38] Shaw, W. H. (2008). Business Ethics. USA: Thomson Wadsworth.

[39] Smith, A.C. \& Grosbois, D.(2010). The adoption of corporate social responsibility practices in the airline Industry. Journal of Sustainable Tourism, 19(1): 59-77.

[40] Sweidan, N. M. \& Haddad, S. I. (2006). Marketing: Contemporary concepts. Dar Al Hamid Publishing and Distributions. Amman, Jordan.

[41] Talafha, A. D. A. (2008). The Impact of Change Management on Achieving the Competitive Advantage for Jordan Telecom Group, Unpublished Master Thesis, Jordan University, AmmanJordan.

[42] Victoria E. Johnson, Linda \& L. Brennan (2002), Examining the impact of technology on social responsibility practices, in (ed.) Re-Imaging Business Ethics: Meaningful Solutions for a Global Economy (Research in Ethical Issues in Organizations, Volume 4), Emerald Group Publishing Limited, pp.107-123 


\section{AUTHORS' BIOGRAPHY}

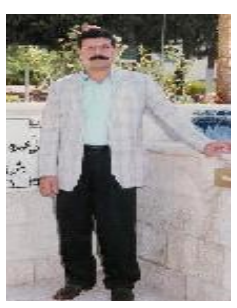

Mohammad Fadel Al Mahasneh, is a lecturer at the Department of Antiquities and Tourism in Mutah University, Jordan. He obtained his master degree in Universiti Utara Malaysia in the area of Tourism and Environment, focusing on the issue of environmental management in the hotel sector. Currently he is pursuing his $\mathrm{PhD}$ in Tourism and HospitalityManagement at the Al Mansoura University, Egypt.

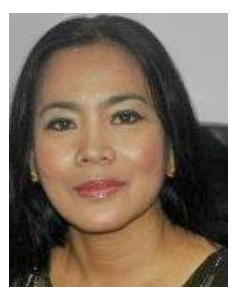

Azilah Kasim, is a professor the School of Tourism, Hospitality and Environmental Management, Universiti Utara Malaysia, Sintok, Kedah, Malaysia. She obtained her degree from Brock University, Ontario, Canada; Master degree from Michigan State University, USA and Doctoral degree from University of East Anglia, United Kingdom. She is currently a national/regional representative and board member for Asia Pacific Tourism Association (APTA) and an associate research fellow for Brunei Indonesia Malaysia Philippines -East ASEAN Growth Area (BIMP-EAGA) division, Universiti Malaysia Sabah. She is also in the Advisory Board of the Asia-Pacific Journal of Innovation in Hospitality and Tourism (APJIHT) and an active ad hoc reviewer for many international journals in her field. Her research interests include corporate social responsibility, hotel management and tourism marketing. 